\title{
PROJECT-AND-PERSONALIZED PARADIGM OF EDUCATION: SOCIAL-AND-ANTROPOLOGICAL CONTEXTS
}

\section{ПРОЕКТИВНО-ОСОБИСТІСНА ПАРАДИГМА ОСВІТИ: СОЦІАЛЬНО-АНТРОПОЛОГІЧНІ КОНТЕКСТИ}

\section{Beilin Mikhail ${ }^{1}$ \\ Karpets Lyubov ${ }^{2}$ \\ DOI: http://dx.doi.org/10.30525/978-9934-571-27-5_5}

Abstract. The purpose of the paper is to carry out the philosophical conceptualization of the projective-and-personal education paradigm, to define the essence, place and role of education in the life strategies of modern humans. Research methodology use as the basis of the study the principles of philosophical anthropology, which allow to consider and analyze the educational principles of the human self-affirmation, the formation and deployment of his I-concept. According to the principle of humanism, the goals, forms, content and methods of teaching in higher education should be oriented towards the personality (or rather, the projective personality) of the student. "Humanizing" education as a way to "humanize" the economy, politics, the media and other institutions is an urgent need of the present, a pledge of the creativity freedom, human rights and freedoms, enshrined in the provisions of national programs and documents of strategic direction. Subject of research. Education is an important component and factor in the human capital formation - all that creates the potential of the individual, increases his ability to solve life problems, and improve qualitatively the most important competencies of a person and a citizen. The education system ensures the preservation and reproduction of the fundamental society values, supports sustainable development and prepares the necessary changes. At the beginning of the XXI century, the understanding of the place, role and value of education is significantly changing and get-

\footnotetext{
${ }^{1}$ Dr. hab. of Philosophy, Associate Professor,

Professor of the Department of Humanitarian Sciences,

Kharkiv State Academy of Physical Culture, Ukraine

${ }^{2}$ Dr. hab. of Philosophy, Associate Professor,

Professor of the Department of Humanitarian Sciences,

Kharkiv State Academy of Physical Culture, Ukraine
} 
ting deeper. A new way of knowledge is formed, as well as a new image of a specialist and higher education as reflected in the projective-and-personal education paradigm. We are eyewitnesses and participants in the emergence of the new social reality features with other dimensions of space and time, new speeds and unprecedented opportunities in the comprehension of the world, understanding of human nature, in achieving of new living standards. Qualitative changes in revolutionary character are taking place at the intersection of digital technologies (digital-revolution), biotechnologies, linguistics, robotics, etc. "Day of risk" turns into an era of rising turbulence, and nobody is able to predict its consequences: humanity is undergoing a phase of military conflicts, revolutions, the destruction of authoritarian regimes, the revitalization of fundamentalism and terrorism. All this places on the agenda the search for ideological landmarks that would allow a person to find the basis for optimism, adequate guides and guides, which will serve as a guarantee of confidence in the fundamental human values. Conclusion. The projective-and-personality education paradigm represents a higher level of a person's life project formation, in which education acts as a constitutive element and an important adjustment factor in life strategies, competence as a specific configuration and practical orientation of different types of intelligence, which, combined with practical skills and experience, allow you to successfully adapt to changing conditions, anticipate and successfully solve emerging problems; it is proved that knowledge is the way and the result of sense production, and information is the resource and the potential for knowledge creating; the competence bases of educational strategies, which should be focused on the intellectual principles and personal dimensions improvement, universal and vocational education are substantiated; reveals the content of intellectual strategies aimed at educating of future professionals who will act as initiators and participants in innovative processes.

\section{1. Вступ}

Сьогодні процес становлення інформаційного суспільства супроводжується різким зростанням обсягу знань та інформації, які втілюються в суспільну практику утвердженням ідей культурного й цивілізованого плюралізму, множинної ідентичності особистості. Знання постає як практика та умова адекватного освоєння проблемного поля людського існування. Проективно-особистісна парадигма освіти в 
умовах інформаційного суспільства стирає межі між традиційними структурно-інституціональними формами освіти (школа, коледж, ВНЗ тощо) й мас-медійними інститутами, які стають реплікаторами нових форм освіти. Однією 3 характерних рис сучасної ситуації людини інформаційного суспільства $\epsilon$ кризовість, яка стосується всіх аспектів соціального буття та актуалізує не лише критико-аналітичні, але й прагматичні функції соціально-гуманітарних наук. Умовою подолання сучасної кризи інформаційного суспільства $є$ перебудова форм життєдіяльності людини й корегування траєкторії соціально-культурного розвитку. Особливої актуальності набувають соціально-філософські прогнози щодо розвитку системи освіти, а тому нагальною є необхідність обгрунтування проективно-особистісної парадигми освіти як евристично-продуктивної моделі, яка б вдало вписувалась у сценарії розвитку науки, культури, техніки, економіки в інформаційному суспільстві.

\section{2. Системні соціально-антропологічні характеристики освіти}

Упродовж усього життя людство знаходиться у пошуках шляхів до цілісного світу, одним із критерієм якого є освіта, як унікальне суспільне явище, що суттєвим чином впливає на людину. Кожна епоха має своє філософське бачення людини, свої уявлення про людський ідеал і відповідну йому освітню парадигму. Протягом багатьох століть «відбувається зміна філософсько-антропологічних основ освіти, пов'язаних зі зміною як уявлень про людину, так і методів, зразків і способів іiї виховання» [6, с. 23].

Як у християнській системі цінностей особистісна самобудова базується на духовних істинах віри, так і в сфері секулярній є початок, який визначає світогляд, діяльність, а ширше - самореалізацію людини щодо власного становлення. Особистісний розвиток у процесі освіти визначає орієнтаційні пріоритети і $є$ процесом входження в освітній простір, осягнення світу - діяльнісним буттям у соціумі. У філософському плані адекватна сучасним викликам освіта постає як спосіб виробництва сутності й розуміння; особистість уже не лише «пристосовується» до існуючого досвіду, а формує під час навчання індивідуальну позицію, тобто знаходиться в процесі становлення i розвитку; уже не освоєння знань, при всій їх безсумнівній важливості, визнається домінуючим, а вивільнення творчого потенціалу особисто- 
сті; справжнім стають знання, які утворюються в процесі осмислення, рефлексії щодо обговорюваної предметності. Освітня реальність формує образи всесвіту і людини, забезпечуючи становлення особистості, яка перебуває в освітньому просторі і здатна до широкомасштабного освоєння інформаційного суспільства.

Стан розвитку сучасної цивілізації, наростаючі процеси змін у індустріальному суспільстві та роль інформації як вирішального ресурсу цивілізаційного розвитку виводять на перші позиції людську діяльність стосовно створення культури протопроективної й проективної організації «всього духовного» в нерозривному зв'язку 3 електронними технологіями, комп'ютерами, глобальним вираженням культури проективності. В цивілізаційній перспективі намічається співорганізація людини й біосфери, суспільства й природи, культури й технології, яка визначає проективно-особистісну парадигму освіти. Особливістю прогностичної методології $є$ те, що критеріально-ідентифікаційною ознакою парадигми освіти є не набір педагогічних ознак, а системні соціально-антропологічні характеристики. Серед парадигм освіти можна виділити: 1) адаптаційно-трансмісійну освіту; 2) сакрально-особистісну освіту; 3) культурно-трансмісійну освіту; 4) соціально-проективну освіту; 5) освіту соціальної інженерії; 6) проективно-особистісну парадигму. Перші три парадигми освіти співвідносяться $з$ давнім періодом антропосоціогенезу, від неолітичної революції до формування цивілізацій, коли соціально-культурний досвід залишався синкретичним, а всі знання були вплетені в загальне полотно культури, в міфи, традиції та ритуали.

Соціально-особистісна й соціально-трансмісійна парадигма освіти співвідносяться з історичним періодом від епохи давньої цивілізації до Нового часу, коли буття людини й суспільства було детерміноване, перш за все, релігією й жорстокою ієрархією соціальних відносин, підпорядковуючи освіту трансляції релігійних вірувань, закріпленню незмінних соціальних структур. Новий час характеризується десакралізацією буття, руйнуванням середньовічних соціальних відносин та інтенсивним розвитком науки й технологій, що об'єктивно обумовлює прагнення всіх інтенцій соціуму на майбутнє, створене на основі науково-технічної могутності й прагнення до підкорення природи, а головне - на основі «технологічної організації» суспільства за образом і подібністю до механічних систем, конвеєра і конвеєрної форми 
виробництва. Відповідно й освіта в цих умовах набуває масового характеру, вона підпорядкована, перш за все, оволодінню й трансляції прагматичних знань, формуванню й відтворенню масової культури споживання. Саме ця модель освіти вступила в протиріччя з сучасним етапом антропосоціогенезу, на зміну їй поступово приходить проективно-особистісна парадигма освіти.

«Парадигмальні зрушення» в освіті детермінуються комплексом об'єктивних факторів соціального порядку, формами соціальності й типом особистості, які, в свою чергу, обумовлені конкретно-історичними особливостями цивілізаційних процесів, зводячи до мінімуму роль суб' єктивного фактору в процесах формування парадигми освіти. На нинішньому етапі цивілізаційного розвитку зростає значення сектору, що обслуговує галузь інтелектуальної діяльності, підсилюється роль інформаційного сервісу, який здійснюється засобами інформаційних технологій.

У сучасному інформаційному суспільстві підсилюється значення інформації і знання в інтерпретації дійсності і формування векторів особистісного розвитку (зростання ролі фактору знання в життєдіяльності соціуму має на увазі розширення інформаційного «обслуговування» всього різноманіття суспільних процесів, яке здійснюється в основному засобами масової інформації), вносячи нову сутність у ціннісно-світоглядну систему освіти. Протиріччя між можливим і дійсним у формуванні образу освітньої реальності в контексті сучасних соціокультурних трансформацій у певній мірі визначені неузгодженістю між тим, що означає й означуваним, суть яких окреслено в терміні «інформаційне суспільство»: це суспільство має вагомі підстави називатися «суспільством знань» або, як зазначалося на Другому міжнародному конгресі ЮНЕСКО з питань технічної і професійної освіти (Сеул, 1999), - «ерою знань, інформації і комунікації». Справді, з одного боку, інформація пов'язує різні рівні і плани суспільного існування та дійсності, забезпечуючи становлення нового типу організації: перетворювальний вплив інформаційно-комунікаційних технологій відчуває нині більшість соціальних інститутів; інформаційні технології стають важливим стимулом розвитку економіки, значним фактором функціонування світових ринків інформації і знання, капіталу й праці, розвитку науки та освіти; зміни в інформаційній сфері, викликані стрімким розвитком і розповсюдженням нових технологій, здійснюються 
в глобальному масштабі. На сьогодні формується індустрія виробництва різноманітного інформаційного змісту, але це лише певна частина доказів на користь адекватності поняття «інформаційне суспільство» сучасному цивілізаційному етапу. 3 другого боку - інформація $\epsilon$ хоча й важливим, але не визначальним стратегічним ресурсом суспільства; статусом такого ресурсу наділяються знання. Таким чином, сучасне інформаційне суспільство - це глобальна інфраструктура, в якій обмін інформацією не має ні часових, ні просторових, ні політичних меж; де відбувається зростання ролі знань, інформаційних комунікацій, інформаційних продуктів і послуг у валовому внутрішньому продукті, становлення «молекулярної» (Д. Тапскотт) структури (розпад адміністративно-командної ієрархії, перехід до мобільних - «бригадних» форм), міжмережева взаємодія, конвергенція ключових галузей економіки та інші нові явища в сферах технології, зайнятості, організації та управління, освіти й культури. Сучасна об'єктивна реальність - це лише повсюдне використання комп'ютерів, інформаційних технологій і Інтернету, де за поняттям «інформація» приховується саме комунікація, а не знання, оскільки пріоритетні позиції посідає тиражування, а не створення інтелектуального продукту, передача даних про нього через засоби масової інформації та мережу Інтернет.

Методологічна окресленість стосовно того, що усвідомлення дійсності передбачає визначення поведінкових переваг, здійснюється у сфері реального й духовного світобачення і є в процесуальному аспекті взаємопроникненням соціального та особистісного, розгортається індивідуальними актами вибору, як способами орієнтації у зовнішньому різноманітті, що власне змістовно і визначає вектор діяльності, успішність якої $є$ наслідком адекватності дій соціокультурним викликам. Гіпотетично допустима певна модельна ситуація, в якій взаємодія з навколишнім середовищем вибудовується виключно нормативними настановами; в практичній площині переважає проблема умов, які детермінують можливий рівень розвитку тих або тих особистісних характеристик. Суттєве поєднання освіти, суспільства, техніки й культури логічно виводить на формулу відповідності особистісних соціокультурних стратегій, які домінують у певний момент суспільного очікування.

Реалії світового розвитку свідчать, що деякі смислові футурологічні прогнози, які обгрунтовують зниження значення матеріального 
виробництва, в цілому не знаходять підтвердження в дійсності, так як і передчасно говорити в глобальному масштабі про реальний вихід на пріоритетні позиції в структурі системи цінностей знань, інтелектуальної діяльності, які потіснили інтереси матеріального достатку й власності. У контексті реалізації «інформаційного проекту» в сенсі повсюдного вирішення матеріальних проблем, забезпечення високої якості безперервності освіти, торжества знання і високих технологій у всіх галузях діяльності, розглядаються приклади, коли суспільні очікування, які здавалися справою віддаленого майбутнього, стрімко стають повсякденною практикою (успіхи мобільного зв'язку, цифрових медіа, систем управління), і навпаки, деякі проблеми, про які раніше заявляли як про уже вирішені, на практиці виявляються далекими від вирішення, а у деяких випадках їхнє розв'язання відкладається на невизначений термін (вирішення проблем політичних і економічних взаємовідносин між провідними державами світу, мирного співіснування, глобалізації тощо).

Освіта - ключова суть умови осягнення досвіду людства в освоєнні природного, соціального й власне культурного світу, сконцентрованого в культурі як способі і формі людського буття, історичній мірі людського способу життя. Особистість освічена, орієнтована на морально-духовні цінності, реалізує й розкриває протягом усього життя все, що закладене природою і набуте в процесі соціалізації. При підході до культури як сукупності цінностей, що обумовлюють сукупність матеріальної, духовної, фізичної і т.д. культури, освітня складова кожного «відгалуження» єдиного «дерева» також очевидна. Розвиток освіти - це творчий процес, у якому закладено прагнення до нової суті. Унікальність феномену освіти полягає в тому, що, втілюючи особистість у культуру, широко розповсюджуючи іiі цінності, вона сама стає культурою, відтворює і розвиває іiі, а освічена особистість постає не лише як продукт, але і творець культури. Виділення як провідної людино-творчої функції освіти розглядається, як рух до онтологічних сенсів, освіта розуміється як цілісне організоване буття людини в культурі. Освіта розгортається як «підйом до всезагального», як специфічний людський спосіб перетворення природних задатків і можливостей (Х.-Г. Гадамер). Те, що з самого початку існує лише як можливість, в освітньому процесі відображається як образ людини. Соціально-антропологічна складова освіти, як важливий атрибут іiї самототожності, 
визначає спрямованість методологічної рефлексії на механізм світовідчуття, світосприйняття та світорозуміння особистості. Онтологічно обгрунтований проективний погляд на майбутнє освіти виходить 3 екзистенціальної суті останнього, його ідеальних цільових установок, життєстверджувальних ціннісних орієнтирів.

Футурологічні екстраполяції на базі наявного знання у сучасному дослідницькому дискурсі детерміновано і логічно окреслились, зокрема, і як попереджувальний розвиток освіти і як реалізація функцій випереджаючого рефлективного відображення. Передбачається, що освіта як «теорія» завжди буде поступатися «практиці», якщо актуалізується лише нинішній (не говорячи уже про минулий) досвід, i, навпаки, вона викликає підвищений попит, якщо орієнтиром є лише щойно назріваючі тенденції найближчого і віддаленого майбутнього.

Дослідження парадигми освіти є однією із центральних проблем обговорення у філософії освіти, орієнтованої на людину (I. Гердер, В. Гумбольдт, Ф. Шлейермахер та ін.). Однак на початку XXI ст. філософам стає складно охопити зростаюче різноманіття спеціальних даних про освіту. Сьогодні, незважаючи на велику кількість корисних напрацювань, сформовано традиційну парадигму освіти, засновану на принципах сцієнтизму, монологізму, авторитарності й утилітарності, на уявленнях про «одновимірну» людину-функцію, яка себе вичерпала. На початку третього тисячоліття філософська наука намагається знайти і сформулювати такі грунтовні підстави, на яких повинна будуватися сучасна парадигма освіти. Стає очевидним, що суспільству потрібно негайно сформувати нові освітні методи, адекватні сучасним умовам суспільного розвитку. Криза освіти, яка набула світового масштабу, і невдачі різноманітних реформ висувають на перший план «філософське осмислення ситуації, що створилася, вироблення нових світоглядних і аксіологічних орієнтирів» [1, с. 15]. У сучасному суспільстві основою розвитку освіти повинні ставати широкі філософсько-антропологічні дослідження шляхів розвитку соціокультурного виміру буття як окремої людини, так і цілих держав. Філософська антропологія і філософія культури є тією підставою, яка здатна забезпечити систему освіти категоріальними і методологічними засобами розвитку людини у сучасній освітній реальності. Однією з основних проблем у новій освітній парадигмі є проблема «гармонійного єднання знання та віри, їх світоглядного синтезу, повернення людині розуміння сенсу 
iii життя, віри в своє унікальне призначення і знання шляхів найбільш повної життєвої самореалізації, ... необхідності усвідомлення глибинних ментальних основ рушійних сил розвитку цивілізації [2, с. 10].

У другій половині ХХ ст. у західному суспільстві відбулися суттєві соціокультурні зміни, які значно вплинули на формування нової філософської парадигми освіти. Відбувається бурхливий розвиток науково-технічної думки, мають місце дещо знесилені, але все ж тенденції до глобалізації, з характерним для них поступовим відходом від ідей національної держави і трансформацією політичної системи. У філософії освіти, яка прагнула до осмислення цих змін, збереглися принципові настанови некласичної раціональності: антисубстанціалізм, антихолізм, онтологічний і гносеологічний плюралізм, визнання несвідомого як частини свідомості, орієнтація на людську суб'єктивність. Освіта є соціально-антропологічним феноменом, що містить у основі комплексний системний характер, який «виробляє» людина засобами культури, тому «людина ... це істота, яка $\epsilon$ в тій мірі, в якій вона самостворюється особливими засобами, не даними в самій природі» [7, с. 18].

Філософська антропологія презентує систему уявлень про людину i дозволяє відтворити цілісний образ людини за допомогою аналізу суперечливих аспектів іiї природи. Розглядаючи людину як унікальну істоту, філософська антропологія розкриває сутність і природу людини, iіi існування в суспільстві. Діяльність людини здійснюється за рахунок самовизначення і самоздійснення, а в системі освіти вона наповнюється особливим змістом. Обгрунтовуючи методологічні підстави філософської антропології, Б.В. Марков стверджує, що «все, що вміє людина, це продукт культурного розвитку, виховання та освіти. Людиною не народжуються, а стають» [10, с. 17.]. Дослідження впливу філософських ідей на формування уявлень про освітню реальність дозволяє глибше зрозуміти сутність останньої, виявляє взаємозв'язок освіти усередині культури, робить більш явним процес обміну ідеями всередині соціокультурного простору.

\section{3. Проективно-особистісна парадигма освіти}

Побудована на соціально-антропологічних дослідженнях парадигма освіти демонструє педагогічні зразки, концептуально осмислюючи та інтерпретуючи базові моделі освіти. «У філософській антропо- 
логії неодноразово здійснювалися спроби виділення, а також розробки парадигмальної типології базових моделей освіти, які побудовані на різних підставах і дозволяють орієнтуватися в практично нескінченному різноманітті освітніх систем, концепцій, теорій, технологій, методик минулого і сьогодення» [4, с. 7]. Проективно-особистісна парадигма освіти орієнтована на вільну і творчу особистість, сенс існування якої криється в самореалізації в найрізноманітніших формах і проявах. Сьогодні «неминуче зростає суспільна значущість соціокультурних цілей освіти, які передбачають формування у свідомості людини таких пріоритетних цінностей як захопленість, особиста гідність, свобода вибору, саморозвиток, відповідальність, ставлення до праці, чуйність та ін.» [12, с. 137]. Як зазначає М.К. Мамардашвілі, «всі філософські твердження, що мають термін «людина», ніколи не вирішувані на будь-яких антропологічних властивостях» [8, с. 15]. Філософ говорить про те, що людина - єдина істота у світі, яка знаходиться в стані «постійного зановонародження», тому сучасному суспільству необхідний антропологічний підхід у вирішенні проблем освіти, вдосконалення освітнього світогляду в напрямку його антропологізації. Внаслідок цього сучасна соціокультурна парадигма освітньої реальності орієнтована на особистість, іiі індивідуальний саморозвиток i самозміну; кожна людина розглядається як активний учасник освітнього процесу, що впливає на самого себе і власний вибір. У сучасній науці відбувається усвідомлення поліваріантних якостей людини, акцентується осмислення їі як суб'єктивної, діалектичної єдності природного і соціального, тілесного і духовного. Формальна сторона парадигми полягає у тому, що вона виступає як структурно-функціональна організація суб'єктної діяльності в освітній сфері, діє на основі певних процедур і правил (тобто на основі змісту парадигми). Освітня реальність не тільки констатує антропологічну складову освіти, але i спонукає до поглибленого осмислення буття людини в освітньому просторі, формування філософської парадигми як якісно нового етапу розвитку освітньої системи. У зв’язку з цим досить актуальним $\epsilon$ перехід до такої філософської парадигми освіти, яка протиставила б домінуючому інтелектуалізму в освіті особистісну концепцію, тим самим наблизившись до ідеалів сучасного відкритого суспільства. За словами К.Д. Ушинського: «... головний і основний принцип сучасної освіти - антропологічний, спрямований на особистість» [3, с. 58]. 
Стара парадигма освіти, орієнтована переважно на передачу і засвоєння наукових, однозначно інтерпретованих знань, сьогодні вступила в протиріччя з новою парадигмою, що розглядає суспільство і людину в їх цілісності, в культурному та індивідуальному вимірі. У цьому сенсі необхідно формувати нову картину суспільства, в якій характерними рисами освіти є: гармонійне співіснування великої кількості концепцій, неоднозначність інтерпретації результатів, зближення наукових і ненаукових форм пізнання. Сучасна освітня реальність, на наш погляд, повинна антропологізуватися, тобто ставити на чільне місце проблеми буття людини, виокреслити роль знання як засобу збереження, відтворення культури і розвитку соціуму, а не лише як способу задоволення потреб соціально-виробничої практики або чистої науки. Через призму систематизації та інтеграції різних освітніх концепцій на соціально-антропологічній основі в рамках філософської парадигми можна створити цілісний образ людини, яка формується під безпосереднім впливом освітньої реальності інформаційного суспільства. Проективно-особистісна парадигма освіти покликана об'єднати різні аспекти людинознавства в єдину предметну галузь. Вона виходить із принципу цілісності людини - як єдності фізичного і психічного, тілесного і духовного, соціального та індивідуального в ньому, фіксує спрямованість, орієнтацію дослідження та побудову сучасної моделі освітньої реальності. Однак було б нерозумним повністю руйнувати традиційну парадигму освіти, оскільки вона, втілившись в освітній практиці протягом XX століття, забезпечила успіхи культури і цивілізації. Зруйнувати цю систему освіти дощенту означає зруйнувати іiі фундамент. Мова йде не про революційну, а про поступову зміну філософсько-антропологічних підстав освітньої системи, про створення єдиного простору освітньої реальності на основі перетворення філософської парадигми. Під таким простором слід розуміти освітнє середовище, яке від самого початку підпорядковується людині як унікальній творчій особистості, що передбачає діалектично пов'язані процеси іiі інтеграції, адаптації, індивідуалізації та персоналізації.

У постнекласичній раціональності, як специфікації некласичної філософії, здійснено спробу подолати деякі крайнощі й переставити акценти. Мова йде, перш за все, про онтологічний поворот, зроблений Е. Гусерлем і М. Гайдегером: повернення до «речей і слів» стало характерною особливістю основних філософських течій другої поло- 
вини XX ст. - структуралізму, феноменології і герменевтики. Позиції антропоцентризму, волюнтаризму, суб'єктивізму, методологізму виявилися суттєво підірваними, що, проте, не означало повернення до класичного об'єктивізму і трансценденталізму. Людина, як «позитивність», поряд 3 іншими «позитивностями» може розхитати межі «цілісностей», в оточенні яких протікає їі існування, але ніколи не зможе зробити їх повністю прозорими або ж взагалі зруйнувати. Звідси необхідність «методології живого розуміння», міжособистісного спілкування з метою розуміння суті, нерідко прихованої від безпосереднього сприйняття. Людина опиняється не в центрі світу, а на перетині конкретних, локальних, регіональних, дискурсивних і недискурсивних практик i, усвідомлюючи себе носієм декількох дискурсів, повинна працювати в межових зонах і переходах від одного порядку до іншого. У цілому в сучасній структуралістській, феноменологічній та герменевтичній філософії явно простежується націленість на те, щоб знайти аргументи проти невиправданих і безпечних прагнень людини реалізувати свої проекти, не враховуючи минулий досвід людства, 3 обмеженнями, які накладаються життям не лише людей, але і природи. Мова не йде про повернення до класичної раціональності 3 властивими їй фундаменталізмом і універсалізмом, а про критику антропоцентризму волюнтаристського гатунку, який прагне відкинути минуле в ім’я принципово нового майбутнього. Розгортання науково-технічної революції спонукало до життя цілу низку впливових концепцій, які абсолютизували значення науково-технічних і технологічних факторів як вирішальних для подальшого розвитку людства. Реакцією на технократичні і бюрократичні тенденції у західній культурі, які поставили під сумнів свободу людини, іiі право на самовизначення, а також на суб'єктивізм, волюнтаризм, які позбавлять людину основи, стало 3 одного боку, посилення міфорелігійних ідей і концепцій в 1960-1970ті роки, а з другого-широке розповсюдження нігілізму, скептицизму, маргіналізація частини інтелектуалів і молоді. «Проект модерну, зазначає Б.В. Марков, - справді залишився незавершеним, а відмова від нього відбулася з причин швидше зовнішнього, аніж внутрішнього порядку. Інститути вільної спільноти і разом з ними критерії розумності або раціональності виявилися малоздатними і не змогли протистояти бюрократичній технократії. Ці суб'єкти перехопили риторику раціональності для обгрунтування своїх інтересів і тим самим дискре- 
дитували їх» [9]. Не дивлячись на суттєві зміни в розумінні розуму, його меж і можливостей, які утвердилися в некласичній раціональності, проблема розумності людини, проблема їі стосунків з іншими, з суспільством, історією не втрачає своєї актуальності. На сучасному мультикультурному тлі аналіз впливу основних принципів постнекласичної філософії освіти в розвинених західних країнах здається вкрай важливим, оскільки сучасна філософія пропонує принципи, здатні виступити основою для інтерпретації тих або тих явищ. Не дивлячись на інновації, які у першій половині XX ст. відіграли суттєву роль в переоріснтації освіти на нові принципи і методи навчання, освіта в цілому залишалася вірною традиційним підходам. Педагогічні експерименти Д. Д'юї і С. Френе, М. Монтессорі і багатьох інших учених і педагогів-новаторів значно підірвали позиції класичної моделі освіти, але не змогли суттєво змінити ії вигляд. Система освіти другої половини XX ст. зіткнулася з такими проблемами, які змусили говорити про іiї глибоку кризу і необхідність перегляду всієї молодіжної політики великих індустріальних держав. Молодіжний бунт 1960-х років, в якому брали участь шкільна молодь і вчителі, свідчив про незадоволеність молодих людей не стільки системою освіти, яка існувала на той час, скільки перспективами «індустріального суспільства», «суспільства споживання». Застереження Х. Ортегі-і-Гасета, М. Гайдегера, К. Ясперса і багатьох інших філософів проти деіндивідуалізації, масовості, які нівелюють особистість, бездушного технічного раціоналізму і бюрократії, які породжували новий тип людини - «життєрадісного робота» (О. Хакслі) або «одномірної людини» (Г. Маркузе), набули нового звучання в умовах швидкого науково-технічного розвитку i посилення регулюючої ролі держави.

Свого часу спроба ліворадикального молодіжного руху реалізувати на практиці ці ідеї показала обмеженість деяких теоретичних принципів некласичної філософії. Мова йде про тотальне заперечення минулого в ім'я майбутнього, про відмову від апологетичного розуму на користь продуктивної сили несвідомого (звідси стає зрозумілим гасло «будьте реалістами - вимагайте неможливого»), про спроби на практиці створити «контрсуспільство» (community) з «контркультурою», яка немає нічого спільного з існуючими. Створення будь-якого роду «альтернативних систем» - «звільнені» навчальні заклади і молодіжні комуни з їх оригінальною культурою розглядалися як найбільш важ- 
ливі плоди цього широкомасштабного соціального бунту. Практика показала неможливість створення суспільства всередині суспільства, а тому багато починань у цьому напрямку не отримали широкої підтримки. I все ж ліворадикальний молодіжний рух відіграв величезну роль в демократизації освіти, яка стала більш доступною для вихідців з малозабезпечених сімей, у збільшенні кількості шкіл і вищих навчальних закладів та покращенні їх фінансування, у переорієнтації шкільної освіти на нові принципи, у зміні змісту навчання, у досягненні більшої незалежності навчальних закладів від прямого втручання держави, в розширенні їх прав як громадянського інституту i у справі самоуправління, що дозволило говорити про «революцію в освіті», про перетворення освіти в «соціальний ліфт». Раціоналізація всіх сфер суспільного життя не змогла обійти і проблеми інтелектуальної освіти, цінність якої дуже похитнулася у попередній період, особливо в рамках концепцій «вільного виховання». Прагнучи з'ясувати причини світової кризи освіти, Ф. Кумбс вбачає однією із основних розрив між системою освіти, яка розвивається повільно, і новими соціальними потребами, що виникли в результаті бурхливого розвитку науки і техніки. «Криза настала в пору істинного торжества знання, пише він, - а освіта, яка слугує першоджерелом і розповсюджувачем знання, не змогла виконати відносно самої себе тієї дослідницької, аналітичної функції, яку вона виконує у суспільстві. Вона не змогла збагатити педагогічну професію новими знаннями і методами, які могли б знайти застосування в аудиторії» [5, с. 12-13]. Кумбс піддає рішучій критиці позиції «традиціоналістів», тобто прихильників «класичної» освіти за те, що вони ігнорують вимоги науково-технічного прогресу, прагнуть зберегти фундаментом у навчальному процесі гуманітарний напрямок, тобто давні й сучасні мови, «вбачаючи у цьому ключ до розуміння своєї і чужої культури» [5, с. 120]. Не менше заважає виходу із кризи і система «селективної освіти», під якою Кумбс має на увазі «вільні школи». Вільне виховання, яке отримало широкий резонанс у першій половині XX ст., він оцінює не з точки зору його спрямованості на вільний індивідуальний розвиток, а як фактор селекції учнів, який суперечить ідеї демократичної освіти. Крім того, перепони, які виникають на шляху отримання освіти всіма, хто бажає їі отримати, служать гальмом науково-технічного прогресу, від якого залежить благополуччя нації. Хоча селективна освіта, на думку Кумбса, підтри- 
мує високу якість навчання, вона поповнює ряди еліти і не відповідає сучасній політиці «відкритих дверей».

Необхідно організувати процес навчання так, щоб людина могла оволодіти якомога більшим обсягом знань без втрати якості і виховувати повагу і звичку до фізичної праці, без якої оволодіння технічними спеціальностями неможливе. У певній мірі Кумбс висуває ті ж вимоги до освіти, що висловлювали раціоналісти початку XX ст., а саме повернути освіту до життєвої практики, враховуючи індивідуальні особливості учнів, розвивати в них прагнення до самоосвіти, до самостійності, але при цьому акцент ставиться на «принципі поєднання людської енергії і технічних можливостей, які дозволяють отримувати «максимум користі із нових технічних засобів». Точка зору Кумбса, хоча й далека від філософських міркувань, але наведена як типова для прихильників необхідності узгодженості освіти 3 потребами науково-технічної революції середини XX ст. Для підтвердження можна навести ще одну схожу думку, яка належить А. Тоффлеру, який розглядав 1960-1970-ті роки як початок становлення суперіндустріального суспільства, чий лозунг - «Знання - це зміни». Прискорення у здобутті знань тягне за собою і прискорення змін, зростання темпу життя, нестабільність економіки, розрив звичних соціальних зв'язків, диференціацію суспільства, утворення множини субкультур, розширення ступенів свободи людини тощо. Характерна риса сучасної індустріальної революції, за Тоффлером, - трансценція (швидкоплинність), тобто нова темпоральність у повсякденному житті, результатом якої є настрій і почуття непостійності [11, с. 36]. Друга риса індустріальної революції - новизна, яка приносить значну кількість інновацій у життя людей, примушуючи їх зіштовхуватися 3 незнайомими інститутами і незвичними ситуаціями. Як наслідок, майбутнє уявляється нескінченною, безперервною низкою дивних подій, сенсаційних відкриттів, неймовірних суперечностей і нових дилем. Це означає, що багато членів постіндустріального суспільства ніколи не будуть у ньому «почувати себе як дома». Вони подібні мандрівникові, який, ледь облаштувавшись на чужині, переселявся щоразу до іншої країни, постійно відчуваючи, що він «чужий серед чужих». Сьогодні люди не готові до таких змін і відчувають, на думку Тоффлера, культурний шок, який свідчить про руйнування звичних механізмів адаптації. Слід зазначити, що чим чіткіші обриси суспільства майбутнього, тим стає 
очевиднішим те, що одним із важливих елементів соціокультурного буття є система освіти. Процес пізнання постає як процес розуміння, який розкриває в діалогічній взаємодії людей сенс явищ навколишньої дійсності, сенс минулих подій, які не втрачають актуальності, але в процесі переосмислення набувають нового значення. Інакше кажучи, знання не акумулюються, а переструктуруються, перебудовуються на нових принципах і втілюються в новий контекст, створюючи можливості подальшого творчого переосмислення.

Диверсифікація в сфері освіти і посилена індивідуалізація, необхідні для успіху постіндустріального суспільства, можуть призвести до ще більшого розриву зв'язків між людьми. Освіта повинна прививати навички, необхідні для людської комунікації і соціальної інтеграції. В умовах інформаційного суспільства розширення комунікативних можливостей людини й динамічності соціального життя ослаблюють довіру і дружні відносини між людьми, а тому освіта «повинна знайти нові шляхи, прискорити розвиток дружби, або шляхом створення більш творчих угрупувань, або в інших видах робочих груп - освіта повинна навчити нас вступати у відносини з людьми» [11, с. 339]. Крім того, різноманітність і складність рішень у постіндустріальному суспільстві актуалізує проблему вибору альтернатив, що вимагає від людини наявності чітко сформованої системи ціннісних орієнтирів.

Освіта є не відокремлена сфера людської життєдіяльності, а спосіб людського існування, що забезпечує можливість знаходження спільного при збереженні відмінностей. Сучасна освітня реальність характеризується різноманітністю навчальних закладів, плюралізмом програм, форм, методів, прийомів навчання та передбачає у своєму змісті різні, іноді альтернативні концепції і підходи. Крім того, учасники освітнього процесу наділені індивідуалізованим світобаченням, власною системою ціннісних орієнтацій, які відображають багатовимірність сучасного суспільства. У цих умовах досить природними $€$ ситуації, коли відбувається порушення комунікації: люди, посідаючи різні позиції навіть щодо одних і тих же питань та проблем, не розуміють один одного, говорять «різними мовами», що призводить до неузгодженості їх діяльності. Спільна мова «розігрується» між тими, хто робить спроби спілкування - вони поступово можуть почати домовлятися, тому навіть тоді, коли різні погляди непримиренно протистоять один одному, існує можливість домовитися між 
собою. Діалог можна вважати сформованим тоді, коли ті, хто вступили в нього, вже не можуть зупинитися на розбіжності, 3 якої їх розмова почалася. Моральна і соціальна солідарність виявляється можливою лише завдяки спільності, яка перестає слугувати вираженням «моєї» або «твоєї» думки, як загального способу світорозуміння. Варто зазначити, що діалог - не просто раціональний процес, який призводить до консенсусу, але морально замальоване дійство, яке вимагає від кожного учасника розмови моральних зусиль, поваги до точки зору іншого, критичної переоцінки власних позицій, готовності змінити свій погляд. Проте далеко не всі люди, з різних причин, здатні до розмови, і це гостро відчувається найбільше там, де вона життєво необхідна - в освітньому просторі. Комунікативно-діалогове навчання передбачає не лише дискусію, обмін думками, пошук нових рішень у межах традиційної урочної форми, але й реалізується в різного роду рольових іграх, які імітують і моделюють життєві ситуації. Поряд 3 рольовими іграми, в яких освоєння ролей відбувається з урахуванням їхньої постійної трансформації, широкого розповсюдження отримали навчальні ігри, які покликані розвивати творче начало в учнів шляхом імітації різних соціальних, історичних, професійних ситуацій і тим самим підготувати їх до життя у суспільстві, де відбуваються постійні зміни. Із розвитком інформаційних технологій поширилися навчальні комп'ютерні ігри, у яких ставиться завдання самостійно вибирати із різних альтернатив, прораховувати наслідки прийняття своїх рішень $\mathrm{i}$ нести за них відповідальність. Оскільки в іграх активізується не лише раціонально-пізнавальне, але й діяльнісно-вольове, творче начало, гра сприяє і розвитку емоційно-образного, художньо-естетичного мислення особистості.

Таким чином, проективно-особистісна парадигма освіти постає як системна теорія, що базується на філософсько-антропологічних підставах і дозволяє розглядати людину як суб'єкта освітніх відносин.

\section{4. Висновки}

Проективно-особистісна парадигма освіти втілюється у повсякденний буттєвий контекст самовизначення особистості, спрямовуючи процес індивідуально-особистісного становлення в просторі проблемного поєднання соціокультурної сутності й людської суб'єктивності. Усвідомлення початкової індивідуальної приналежності до світу куль- 
тури - динамічної конструкції, яку створює людина, обумовлюючи різноманітність аспектів орієнтування у навколишньому світі, стимулює формування ціннісних категорій, змістовних установок індивідуального буття як факторів самостворення особистості у макросвіті освітньої реальності.

\section{Список літератури:}

1. Антипин Н.А. (2003). Мировоззренческие и методологические проблемы разработки философии образования для XXI века. Инновации и образование (сб. матер. конф.). Серия "Sуmposium”, вып. 29: 15-27.

2. Гершунский Б.С. (2001). Готово ли современное образование ответить на вызовы XXI века? Педагогика, 10: 3-12.

3. Голубева О.Н., \& Суханов А.Д. (1996). Проблемы целостности в современном образовании. Философия образования: 58-62.

4. Колесникова И.А. (1999). Педагогическая реальность в зеркале межпарадигмальной рефлексии. Изд-во С.-Петерб. гос. ун-та: 242 с.

5. Кумбс Ф.Г. (1970). Кризис образования в современном мире. Системный анализ. Москва: Прогресс: 261 с.

6. Липская Л.А. (2007). Философско-антропологический фундамент современного образования. Науч. онлайн-библиотека «Порталус»: 23-28. [Электронный ресурс] - Режим доступа : http://portalus.ru/modules/shkola/ rus_show_archives.php?subaction $=$ showfull\&id $=1193922911 \&$ archive $=11968148$ 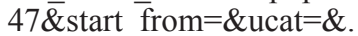

7. Майер Б.О., \& Наливайко Н.В. (2008). Об онтологии качества образования в обществе знания. Философия образования, 3(24): 4-17.

8. Мамардашвили М.К. (1991). Проблема человека в философии. О человеческом в человеке. Москва: Политиздат: 8-22.

9. Марков Б.В. (2001). Образование и познание в процессе цивилизации. Онтология возможных миров. Изд-во С.-Петерб. гос. ун-та: 203-218.

10. Марков Б.В. (1997). Философская антропология: очерки истории и теории. СПб.: Изд-во «Лань»: 384 с.

11. Тоффлер А. (1997). Футуршок. СПб.: Лань: 464 с.

12. Эмих Н.А. (2010). Роль толерантности в преобразовании системы современного образования. Вестник Читинского государственного университета. Серия: Философия. 2(59): 137-140.

\section{References:}

1. Antipin N.A. (2003). Mirovozzrencheskie i metodologicheskie problemy razrabotki filosofii obrazovaniya dlya XXI veka. Innovacii i obrazovanie (sb. mater. konf.). Seriya "Symposium", vyp. 29: 15-27.

2. Gershunskij B.S. (2001). Gotovo li sovremennoe obrazovanie otvetit' na vyzovy XXI veka? Pedagogika, 10: 3-12.

3. Golubeva O.N., \& Suhanov A.D. (1996). Problemy celostnosti v sovremennom obrazovanii. Filosofiya obrazovaniya: 58-62. 
4. Kolesnikova I.A. (1999). Pedagogicheskaya real'nost' v zerkale mezhparadigmal'noj refleksii. Izd-vo S.-Peterb. gos. un-ta: $242 \mathrm{~s}$.

5. Kumbs F.G. (1970). Krizis obrazovaniya v sovremennom mire. Sistemnyj analiz. Moskva: Progress: $261 \mathrm{~s}$.

6. Lipskaya L.A. (2007). Filosofsko-antropologicheskij fundament sovremennogo obrazovaniya. Nauch. onlajn-biblioteka "Portalus": 23-28. [Electronic resource] - Access mode: http://portalus.ru/modules/shkola/rus_show_archives. php? subaction $=$ show full\&id $=1193922911 \&$ archive $=1196 \overline{8} 1484 \overline{7} \&$ start from $=$ \&ucat $=\&$.

7. Majer B.O., \& Nalivajko N.V. (2008). Ob ontologii kachestva obrazovaniya v obshchestve znaniya. Filosofiya obrazovaniya, 3(24): 4-17.

8. Mamardashvili M.K. (1991). Problema cheloveka v filosofii. O chelovecheskom v cheloveke. Moskva: Politizdat: 8-22.

9. Markov B.V. (2001). Obrazovanie i poznanie v processe civilizacii. Ontologiya vozmozhnyh mirov. Izd-vo S.-Peterb. gos. un-ta: 203-218.

10. Markov B.V. (1997). Filosofskaya antropologiya: ocherki istorii i teorii. SPb.: Izd-vo "Lan'»: $384 \mathrm{~s}$.

11. Toffler A. (1997). Futurshok. SPb.: Lan': 464 s.

12. Ehmih H.A. (2010). Rol' tolerantnosti v preobrazovanii sistemy sovremennogo obrazovaniya. Vestnik Chitinskogo gosudarstvennogo universiteta. Seriya: Filosofiya. 2(59): 137-140. 